\title{
Students Learning Outcome of Social Studies at Junior High Schools Reviewed from Social Interaction, School Culture and Achievement Motivation
}

\author{
$1^{\text {st }}$ Wahidul Basri* \\ Doctoral Program Student in Postgraduate \\ Education Universitas Negeri Padang \\ wahidulbasri@fis.unp.ac.id \\ $2^{\text {nd }}$ Mukhaiyar \\ Doctoral Program Student in Postgraduate \\ Education Universitas Negeri Padang
}

\author{
$3^{\text {rd }}$ Syafri Anwar \\ Doctoral Program Student in Postgraduate \\ Education Universitas Negeri Padang
}

\begin{abstract}
This study aims to reveal whether there is a direct influence on social interaction, school culture, and achievement motivation at junior high school students' Social Studies learning outcomes. The method used is a survey method. The technique in this research is path analysis (path analysis). There are 4 (four) variables studied in this study, namely social interaction variable (X1), school culture variable (X2), achievement motivation variable $(\mathrm{X} 3)$, and Social Studies learning outcome variable $(\mathrm{Y})$ as the main endogenous variable. The population in this study were students of the State Public Middle School in Padang. Data collection techniques in this study were carried out by distributing questionnaires and documentation studies on the value of students' social studies learning outcomes. Data analysis techniques using descriptive analysis and inductive analysis (Inferential Analysis). The results showed that 1) There was a direct influence of Social Interaction (X1) on Social Studies Learning Outcomes of Students $(Y)$ in the amount of $3.03 \%, 2)$ there was adirect influence on School Culture (X2) on Social Studies Outcomes of Students (Y) in the amount of $23.33 \%$, 3) there
\end{abstract}

is a direct effect of Achievement Motivation (X3) on Social Studies Learning Outcomes of Students (Y) of $1.59 \%$, 4) there is a direct influence of Social Interaction (X1) on achievement motivation (X3) of $9,86 \%, 5)$ there is a direct influence of School Culture (X2) on Achievement Motivation (X3) in the amount of $4.71 \%, 6)$ there is an indirect effect of Social Interaction (X1) on Social Studies Learning Outcomes of Students (Y) through Achievement Motivation (X3) that is equal to $0.23 \%$, and 7) there is an indirect effect of School Culture (X2) on Social Studies Learning Outcomes of Students (Y) through Achievement Motivation (X3) which is equal to $0.29 \%$. Based on the research findings it can be concluded that: 1) there is a direct influence of social interaction, school culture and achievement motivation on social studies learning outcomes of junior high school students, and 2) there is an indirect effect of social interaction and school culture on social learning outcomes of junior high school students through achievement motivation.

Keywords-Students Learning Outcome, Social Interaction, School Culture, Achievement Motivation 


\section{INTRODUCTION}

Life is more advanced and complex lead to the increasing demands of the life of every individual. This condition requires serious attention to prepare as early as possible for each individual to equip themselves with social skills in dealing with any phenomenon of life. Every individual should be given the knowledge and social skills enough to be able to adjust to the demands of life and the environment. During social transformation that brings more and more negative effects, the school should have called for attention to social and moral development of students

The efforts to achieve intelligence or knowledge are human efforts to meet their needs, namely to gain knowledge or intelligence that has not been previously owned. By learning, humans become know, understand, understand, can implement and have about something. [1] states "learning is a business process undertaken by someone to obtain a new change in behavior as a whole, as a result of his own experience in interaction with the environment". [2] states that learning is a process of changing one's behavior through interaction with the surrounding environment. Learning is a conscious effort made by individuals in a change in behavior through training and experience which involves several aspects, including cognitive, affective, and psychomotor to obtain a particular purpose [3].

While [4] argues that "learning is a change in personality manifested as new response patterns in the form of skills, attitudes, habits, knowledge, and skills".

Based on the meanings above, it can be concluded that learning is a business process carried out by individuals to gain knowledge and experience as well as abilities in cognitive, affective, and psychomotor aspects, which are obtained through the interaction of individuals with their environment.

[5] in general, factors that influence learning outcomes can be divided into two; internal factors and external factors. Students' internal factors are divided into two; psychological and physiological factors, while external factors include environments, teachers, social factors, and learning methods. This is in line with the opinion of [6] in his research which said: "Student learning outcomes are influenced by students' self and the quality of teaching". [7] argues that "learning outcomes are the result of the learning process by using measurement tools, namely in the form of planned tests, both written tests, oral tests and deeds tests". Student learning outcomes are influenced by student self and the quality of teaching. The quality of teaching is teacher professionalism. One of them is how the teacher chooses the learning model. The selection of the right learning model will also affect the improvement of learning outcomes and the achievement of learning objectives. Learning outcomes are described as written statements of what a learner is expected to know, understand and/or be able to do at the end of a period of learning [8]. Learning outcomes described as a written statement of what is expected to be known, understood, and / or can be conducted by participants at the end of the learning period. Student learning outcomes can be seen after the students follow the learning process as a measure of the ability of students to learn a learning material. The student learning outcomes, is influenced by various factors, both factors in the student's own or factors outside the student.

Social knowledge is the development of students' understanding of how humans as individuals and groups live together and interact with their environment both physically and socially. Learning social education or social knowledge aims to students can develop social knowledge, attitudes, and skills, which are useful for the progress of themselves as individuals and as members of the community [9]. Thus Social Studies has a very important role, namely to educate students to develop knowledge, attitudes, and skills so that they can actively take part in their lives as members of 
society and good citizens, namely citizens who are proud and love their homeland.

Interaction is a relationship between two systems that occur in such a way that events that take place on one system will affect events that occur in the other system. Interaction is a social relationship between individuals in such a way that the individuals concerned affect each other [10]. Other forms of social processes are only specific forms of social interaction. Social interaction is a dynamic social relationship that involves the relationship between individuals and human groups [11]. [12] suggested the social interaction is a dynamic relationship that brings people to people, group by group, and people with a group of men. The shape is not only cooperation, but also the form of the action, competition, strife and the like.

Based on some of the descriptions above, it can be concluded that social interaction is a reciprocal relationship that influences, changes, or improves behavior that takes place between individuals and individuals, individuals and groups, or groups and groups. So social interaction is the ability of an individual in social relations with other individuals or groups with marked social contact and communication.

Many things can be done to improve the quality of education. One of those things is to build good school culture. School culture is an organizational culture in the context of schooling. According to [13] the definition of school culture has not obtained a unified view. The terminology of school culture is still equated with "climate or ethos". The concept of culture in the world of education originates from workplace culture in the industrial world, which is a situation that provides the basis and direction for the process to take place effectively and efficiently [14]. The application of the term culture in organizations, in this case including educational institutions, is relatively new. School culture is a set of values that underlies the behavior, traditions, daily habits, and symbols that are practiced by principals, teachers, administrative officers, students, and the community around the school. School culture is a characteristic, character or character, and the image of the school in the wider community. [15] suggests that school culture acts as a kind of facilitator for principals to empower teachers via their principal leadership. [16] explains that "School culture is a large part of the symbolic approach to organizations". School culture is a big part of a symbolic approach to organizations. school culture also experienced through ritual and ceremony. The school is a formal organization with a specific purpose. School is one of a small community with its own culture. [17] explained that "School culture and teacher leadership are vital in determining school's excellence". School culture and teacher leadership are very important in determining school excellence.

From the above explanations, a common thread can be drawn that school culture is a "pattern of values, norms, attitudes, myths, and habits that are formed in the long journey of a school, as their basis in understanding and solving various problems that arise in schools. Where the school is held jointly by the principal, teachers, administrative staff, and students, motivation can simply be interpreted as an impulse from within the individual which is described as hopes, desires and so on which are activated or move the individual concerned to act and act, in order make ends meet. Motivation is a complex part of human psychology and behavior that influences how individuals choose to spend their time, how much energy they put into each task given, and how they think [18]. [19], explains that internal and external impulses to make changes or do something, generally have several indicators or supporting elements. These indicators can be in the form of (1) the existence of desires and desires, (2) the existence of drives and needs, (3) the existence of hopes and goals, (4) the existence of rewards, (5) the existence of activities or actions, and (6) the existence of the environment. [20] explains that motivation is generally described as an internal condition that stimulates, directs and sustains human behavior. Motivation is generally 
described as an internal condition that stimulates, directs and sustains human behavior.

From the above understanding, it can be said that the motive is a potential force for the occurrence of behavior or action, while motivation is anything that drives a person to carry out activities, both originating from within or from outside the self. Furthermore, motivation is also a process of mobilizing and strengthening a motive to be actualized in real action.

\section{METHOD}

The method used is a survey method. The technique in this research is path analysis (path analysis). In this study, the influencing variables are called exogenous variables, and the affected variables are called endogenous variables. The population in this study were students of the State Public Middle School in Padang. The data collection techniques using questionnaires and social studies learning outcomes of students. Data analysis techniques using descriptive analysis and inductive analysis (inferential analysis).

\section{RESULTS AND DISCUSSION}

\section{Testing Data Distribution Normality}

From normality testing conducted on variables that include variables Social Studies Learning Outcomes of students (Y), Social Interaction $\left(X_{1}\right)$, School Culture $\left(X_{2}\right)$, and Achievement Motivation (X3) the results can be disclosed, while the summary analysis of the normality of data distribution testing is illustrated in the table below.

Table 1 Summary Analysis of Normality Test $(n=217)$

\begin{tabular}{lllcl}
\hline No & \multicolumn{1}{c}{ Variable } & X 2Calculate & Sign. & Conclusions \\
\hline 1. & Social Interaction (X1) & 1.316 & 0.063 & Normal \\
2. & School Culture (X2) & 1.216 & 0.104 & Normal \\
3. & Achievement Motivation (X3) & 0.893 & 0,402 & Normal \\
4 & Learning Outcomes Social Studies (Y) & 1.279 & 0,076 & Normal \\
\hline Description: $\alpha=0.05$ & & &
\end{tabular}

Based the normality test calculation results above can be explained that the hypothesis 0 (nol) for the variable Social Interaction $\left(X_{1}\right)$, School Culture $\left(\mathrm{X}_{2}\right)$, Achievement Motivation variable (X3) and Social Studies Learning Outcomes $(\mathrm{Y})$ can be accepted, meaning in the study this research population is normally distributed, thus it can be concluded that all data from each variable are normally distributed and can be used in the analysis of research studies.

\section{Testing Linearity Relationship}

Table 2 Summary of Results of Linearity Tests The Effect of Research Variables Using Technique $F$ Test

\begin{tabular}{lllll}
\hline No. & Type of Count & Value Fcalculate & Sign Value & Conclusion \\
\hline 1. & $\begin{array}{l}\text { Social Interaction (X1) with Social } \\
\text { Studies Learning Outcomes (Y) }\end{array}$ & 1,040 & 0.416 & Linear \\
\hline 2. & $\begin{array}{l}\text { School Culture (X }) \text { with Social Studies } \\
\text { Learning Outcomes (Y) }\end{array}$ & 1,321 & 0.088 & Linear \\
\hline 3. & $\begin{array}{l}\text { Achievement Motivation ( X3) with } \\
\text { Social Studies Student Learning }\end{array}$ & 2,183 & .097 & Linear \\
\hline
\end{tabular}




\begin{tabular}{|c|c|c|c|c|}
\hline \multicolumn{5}{|c|}{ Outcomes (Y) } \\
\hline 4. & $\begin{array}{l}\text { Social Interaction (X1) with } \\
\text { Achievement Motivation (X3) }\end{array}$ & 0.970 & 0.537 & Linear \\
\hline 5. & $\begin{array}{l}\text { Culture School }\left(X_{2}\right) \text { with Achievement } \\
\text { Motivation }\left(X_{3}\right)\end{array}$ & 1,275 & 0,113 & Linear \\
\hline & $\begin{array}{l}\text { cription: } X_{1}=\text { variable interactions Social } \\
\text { Achievement Motivation Variable }\end{array}$ & $\begin{array}{l}\text { hool Cu } \\
\text { cial Studi }\end{array}$ & le & \\
\hline
\end{tabular}

Based on the results of linearity testing the effect of each research variable conducted through the F-test, shows that there is a linearity relationship between one variable with another variable, meaning based on theoretical the data meets the requirements for use in research hypothesis testing.

\section{Testing the Significance of Regression Coefficient Regression}

An analysis of the influence of the Social Interaction variable $(\mathrm{X} 1)$ on the Social Studies Student Learning variable (Y), Social Studies Learning Outcomes Students as endogenous variables obtained an $\mathrm{F}$ value calculated of 21.469 with a significance of 0.00 , smaller $\alpha=0$, 01 Thus the hypothesis that there is a Social Interaction (X1) on the variable Social Studies Learning Outcomes $(\mathrm{Y})$ is accepted at a significance level of 0.01 . Based on the results of the Farithmetic it can be concluded that the regression equation of the Social Interaction path analysis (X1) on the Social Studies Learning Variables Student $\mathrm{Y}(\mathrm{Y})$ is very significant, so it is categorized as meeting the requirements for testing the research hypothesis by using the path analysis model.

Table 3 Summary of Results of Testing Significance Regression Equations

\begin{tabular}{clccc}
\hline No & \multicolumn{1}{c}{ Line Relations } & F $_{\text {count }}$ & Value Sign & Conclusion \\
\hline 1 & $\begin{array}{l}\text { The interaction of social, 1 (X1) with the } \\
\text { Learning Outcomes IPS Students (Y) }\end{array}$ & 21469 & 0,000 & $\begin{array}{c}\text { Very } \\
\text { Significant }\end{array}$ \\
\hline 2 & $\begin{array}{l}\text { School Culture ( } \mathrm{X}_{2} \text { with Learning } \\
\text { Outcomes IPS Students (Y) }\end{array}$ & 91.931 & 0,000 & $\begin{array}{c}\text { Very } \\
\text { Significant }\end{array}$ \\
\hline 3 & $\begin{array}{l}\text { Achievement Motivation (X3) with } \\
\text { Student Social Learning Outcomes (Y) }\end{array}$ & 24,109 & 0,000 & $\begin{array}{c}\text { Very } \\
\text { Significant }\end{array}$ \\
\hline 4 & $\begin{array}{l}\text { Social Interactions (X1) with } \\
\text { Achievement Motivation (X3) }\end{array}$ & 30,235 & 0,000 & $\begin{array}{c}\text { Very } \\
\text { Significant }\end{array}$ \\
\hline 5 & $\begin{array}{l}\text { School Culture }\left(\mathrm{X}_{2}\right) \text { with Achievement } \\
\text { Motivation }(\mathrm{X} 3)\end{array}$ & 16,963 & 0,000 & $\begin{array}{c}\text { Very } \\
\text { Significant }\end{array}$ \\
\hline
\end{tabular}

Description: $X_{1} \quad=$ Social Interaction Variable $\quad X_{2}=$ School Culture Variable

$\mathrm{X}_{3}=$ Achievement Motivation Variable $\quad \mathrm{Y}=$ Student Learning Outcomes Variable

Based on the test results the significance of the regression equation on the path analysis can be concluded, that the relationship is very significant and thus eligible for use in the research hypothesis testing model path analysis (path analysis).

\section{Hypothesis Testing}

Based on the calculation results of the analysis of the percentage of the above in mind it turns out there is an influence either directly or indirectly, exogenous variables, namely Social Interaction (X1), Cultural School $\left(\mathrm{X}_{2}\right)$, Against 
endogenous variables namely Achievement Students (Y) as summarized below. Motivation (X3) and Learning Outcomes IPS

Table 4 Summary of Analysis of Direct and Indirect Effects of Exogenous Variables on Endogenous Variables.

\begin{tabular}{|c|c|c|c|c|}
\hline No & Information & Direct \% & Indirect \% & Total Amount \% \\
\hline 1 & $\begin{array}{l}\text { Direct Effect of Social Interaction }\left(\mathrm{X}_{1}\right) \text { on } \\
\text { Social Studies Learning Outcomes of } \\
\text { Students }(\mathrm{Y})\end{array}$ & 3.03 & & \\
\hline 2 & $\begin{array}{l}\text { Indirect Effects of Social Interaction }\left(\mathrm{X}_{1}\right) \\
\text { on Social Studies Learning Outcomes of } \\
\text { Students }(\mathrm{Y}) \text { through Achievement } \\
\text { Motivation }(\mathrm{X} 3)\end{array}$ & & 0.23 & \\
\hline 3 & $\begin{array}{l}\text { Direct and indirect effects of Social } \\
\text { Interaction }\left(\mathrm{X}_{1}\right) \text { on Student Social } \\
\text { Learning Outcomes }(\mathrm{Y})\end{array}$ & & & 3.26 \\
\hline 4 & $\begin{array}{l}\text { Direct Effect of School Culture }\left(\mathrm{X}_{2}\right) \text { on } \\
\text { Social Studies Learning Outcomes of } \\
\text { Students }(\mathrm{Y})\end{array}$ & 23,33 & & \\
\hline 5 & $\begin{array}{l}\text { The indirect effect of School Culture }\left(\mathrm{X}_{2}\right) \\
\text { on Social Studies Learning Outcomes of } \\
\text { Students }(\mathrm{Y}) \text { through Achievement } \\
\text { Motivation }(\mathrm{X} 3)\end{array}$ & & 0.29 & \\
\hline 6 & $\begin{array}{l}\text { The direct and indirect influence of } \\
\text { School Culture }\left(\mathrm{X}_{2}\right) \text { on Social Studies } \\
\text { Learning Outcomes of Students }(\mathrm{Y})\end{array}$ & & & 23,62 \\
\hline 7 & $\begin{array}{l}\text { Direct Effect of Social Interaction }\left(\mathrm{X}_{1}\right) \text { on } \\
\text { Achievement Motivation }\left(\mathrm{X}_{3}\right)\end{array}$ & 9,86 & & \\
\hline 8 & $\begin{array}{l}\text { Direct Effect of School Culture }\left(\mathrm{X}_{2}\right) \text { on } \\
\text { Achievement Motivation }\left(\mathrm{X}_{3}\right)\end{array}$ & 4,71 & & \\
\hline 13 & $\begin{array}{l}\text { Direct Effect of Learning Motivation } \\
\text { (X3) on Student Learning Outcomes (Y) }\end{array}$ & 1.59 & & \\
\hline 14 & Effect of other variables & & & 26.88 \\
\hline
\end{tabular}

It turns out that from the results of the above study, it can be concluded that the largest contribution that affects Social Studies Learning Outcomes of Students (Y), both directly and indirectly is derived from the School Culture variable (X2) with a percentage effective contribution of $23.62 \%$. Then, the second-largest contribution was followed by the Social Interaction variable (X1) with an effective contribution percentage of $3.26 \%$. While the influence of the variable Learning Motivation (X3) on Social Studies Learning Outcomes of Students (Y) obtained the smallest percentage that is equal to $1.59 \%$. 


\section{CONCLUSIONS}

The results of the study showed that 1) There was a direct influence of Social Interaction (X1) on Social Studies Learning Outcomes of Students (Y) that is $3.03 \%, 2)$ there was adirect influence on School Culture (X2) on Social Studies Learning Outcomes (Y) namely of $23.33 \%, 3$ ) there is a direct effect of Achievement Motivation (X3) on Social Studies Learning Outcomes of Students (Y) of $1.59 \%, 4)$ there is a direct influence of Social Interaction (X1) on achievement motivation (X3) that is equal to 9 , $86 \%, 5)$ there is a direct influence of School Culture (X2) on Achievement Motivation (X3) in the amount of $4.71 \%, 6)$ there is an indirect effect of Social Interaction (X1) on Social Studies Learning Outcomes of Students (Y) through Achievement Motivation ( X3) that is equal to $0.23 \%$, and 7) there is an indirect effect of School Culture (X2) on Student Learning Outcomes (Y) through Achievement Motivation (X3) that is equal to $0.29 \%$.

\section{REFERENCES}

[1] Slameto. (2003). Belajar dan Faktor-faktor yang Mempengaruhinya. Jakarta: Rineka Cipta.

[2] Hamalik, Oemar. (2011). Kurikulum danPembelajaran. Jakarta: Bumi Aksara

[3] Aunurrahman. (2010). Belajar dan Pembelajaran, Bandung: Alfabeta.

[4] Nana, Syaodih Sukmadinata. (2004). Runway Psychology Education process. Bandung: PT Young Rosdakarya.

[5] Yunanto Efendy, et al. (2019). The Influence of Problem based Learning, Inquiry, and Learning Style to the Students' Learning Outcomes of Social Science Subjects in Junior HighSchools in Indonesia: A Case Study. International Journal of Education and Research, 7(2). ISSN: 2411-5681

[6] Azizan1, et al. (2018). The Influence Of Using Problem Based Learning Models In Studying Civic Education At SMP Muhammadiyah 07 Medan, Indonesia.
International Journal of Education, Learning and Development, 6(9), pp. 51-61.

[7] Kunandar. (2011). As a Class Action Research Teacher Professional development. Jakarta: PT Raja Grafindo Persada.

[8] Taurina, Zane. Students' Motivation and Learning Outcomes: Significant Factors in Internal Study Quality Assurance System. International Journal for Cross-Disciplinary Subjects in Education (IJCDSE), Special Issue 5(4).

[9] Saidihardjo. (2005). Basic Concepts of Social Sciences. Yogyakarta: Ministry of National Education.

[10] Chaplin, JP. (2011). Complete Dictionary of Psychology. Jakarta: King Grafindo Persada

[11] Basrowi. (2014). Pengantar Sosiologi. Bogor: Ghalia Indonesia.

[12] Syahrial Syarbaini and Rudiyanta. (2009). Basics of Sociology. Yogyakarta: Graha Science

[13] Sadulloh, Uyoh. (2006). Introduction to the Philosophy of Education. Bandung: CV. Alfabeta

[14] Zamroni. (2000). Future Education Paradigm. Yogyakarta: Bigraf Publishing.

[15] Maher, MC (2000). A models for understanding the influence of principal leadership upon teacher empowerment as mediated by school culture. Doctoral Dissertation. University of Missouri, Columbia.

[16] Abdullah Abdul and Anantha Raj A. Arokiasamy. (2016). The Influence of School Culture and Organizational Health of Secondary School Teachers in Malaysia. TEM J, 5, pp. 56-59.

[17] Yusof Hamidah dkk. (2016). School Culture and Its Relationship with Teacher Leadership. International Journal of Academic Research in Business and Social Sciences, 6(11). ISSN: 2222-699

[18] Bakar, Ramli. (2014). The Effects of Learning Motivation on's Productive West Sumatra Competencies in Vocational High School. International Journal of Asian Social Science, 4(6),pp. 722732, ISSN (e): 2224- 
4441/ISSN (p):2226-5139. Retrieved from http://ww.aessweb.com/pdffiles /ijass2014-4(6)-722-732.pdf.

[19] Hamzah B. Uno, M. (2010). The theory of motivation and itsmeasurement. Jakarta: PT Earth Literacy

[20] Bal Seçil Taştan et all. (2018). The Impacts of Teacher's Efficacy and Motivation on
Student's Academic Achievement in Science Education among Secondary and High School Students. Eurasia Journal of Mathematics, Science and Technology Education, 14(6), pp. 2353-2366 ISSN:13058223 (online) 1305-8215 (print). 